\title{
上顎全摘後の一期的再建法と問題点
}

\author{
飯塚 桂司・古田康・柏村 正明 \\ 三国 尚志・今野 昭義*

\section{Primary Reconstruction after Total Maxillectomy for Maxillary Cancer}

\author{
Keiji Iizuka, Yasushi Furuta, Masaaki Kashiwamura \\ and Hisashi Mikuni
}

(Kushiro Municipal Hospital)

Akiyoshi Konno

(Chiba University)

We present two patients with maxillary cancer who had facial reconstruction immediately after total maxillectomy. In the first case, Killian-Hoshino's incisional skin line was delineated and total maxillectomy was performed. The orbital floor was reconstructed by free iliac bone graft, and the raw surface was covered with a delayed D-P flap. The second patient has maxillectomy with two skin incisional lines, which are used in lateral rhinotomy and face lift. The orbital content was supported by fascia lata in the shape of a hammock. The raw surface was covered by a free forearm flap. This skin incision gave a more adequate operative field, and a better cosmetic result by preserving the upper lip. We discuss the skin incision line, material for orbital floor reconstruction, and choice of covering the raw surface after maxillectomy.

Key words: maxillary cancer, total maxillectomy, primary reconstruction

はじめに

上顎癌の集学的治療には，機能と形態の保存 の目的のために低線量照射に腫瘍減量術を組み 合わせて行う立場12) と，乙れと反対に全線量 照射，抗癌剂の動注，上顎全摘を行い必要に応 じて即時再建術を行う立場3) 9) がある．前者の 治療理念は上顎全摘という手術的操作が顔面形 態を著しく損ない社会復帰が困難なとと, さら に他の頭頸部癌とは相違して遠隔転移が少なく
局所病変の制御によって，ある程度根治性が得 られる可能性があるというととである。一般の 悪性腫瘍に対する切除術とは異なり, 進展範囲 に応じて周囲の健常組織を含めて腫瘍切除を行 うのではなく，あくまで腫瘍減量術であり，さ らに再発時点で再び対処するという治療法であ るために，長期的にみた根治性に問題があり， また再発症例では顔面のろう孔を形成したり， 瘏痕収縮によって開口障害を生じたりするため 
に必ずしあ社会生活面では良好な結果とはなっ ていない面あある，血管吻合の普及によってさ まざまな遊離皮弁が利用するととが出来るよう になり，再建術が進歩する中で根治性，整容性， 機能性の高い治療法の選択が可能となってきて いる. 今回 2 症例を報告するととあに，上顎全 摘に際してその再建目標とともに手術的アプロ ーチならびに再建方法について検討した.

症例 1 ：50歳，男性.

$\mathrm{T}_{4} \mathrm{~N}_{1} \mathrm{M}_{0}$ ，高度分化型扁平上皮癌. CT スキャ ン（図1）に示されるように，側頭窩に及びさ らに頉粘膜にまで浸潤する高度進展癌症例であ る.5-FU1500 mg/day ${ }^{10)}$ を 5 日間連続末梢静 脈より投与し，さらに浅側頭動脈からの 5-FU $250 \mathrm{mg}$ 隔日動注下に Linac X-ray 60Gy 照射後 飞根治的頸部郭清術，上顎全摘術を施行. 皮膚 切開は, Killian-星野の切開法に準じた. 摘出標 本の病理学的検索にては, 癌細胞は見られず術 前治療の組織学的効果は下里分類 IV であった。 眼窩底を再建する目的にて腸骨からの遊離骨移 植を行い，術創全体を D-P 皮弁にて被服した. 3 週間後に D-P 皮弁を切り離し皮弁の茎を前 胸部へ戻した ${ }^{11}$ (図 2 ). 術後 7 週の $99 \mathrm{mTc}$ 骨



図 150 歳, 男性, $\mathrm{T}_{4} \mathrm{~N}_{1} \mathrm{M}$, 高度分化型扁平上皮 癌. CT scan で示されるように上顎洞後壁が 破壊され側頭窩にまで癌浸潤が及ぶ。
スキャンでは移植骨への集積がみられ，生着し たととを示している(図 3 ).

症例 $2: 71$ 歳, 男性.

$\mathrm{T}_{2} \mathrm{~N}_{0} \mathrm{M}_{0}$ ，未分化癌. 5-FU1500 mg/day を 末梢静脈加 ら持続点滴法にて 5 日間投与 ${ }^{10)}$ し, Linac X-ray 50 Gy 照射後に上頸部郭清術（予 防的）上ともに上顎全摘を施行. 顔面外切開は 側鼻切開と下眼瞼切開とを併せて行った。すな わち側鼻切開は内眼角のやや上方から鼻側に沿 って人中までとし，下眼瞼切開は睷毛の直下ぎ

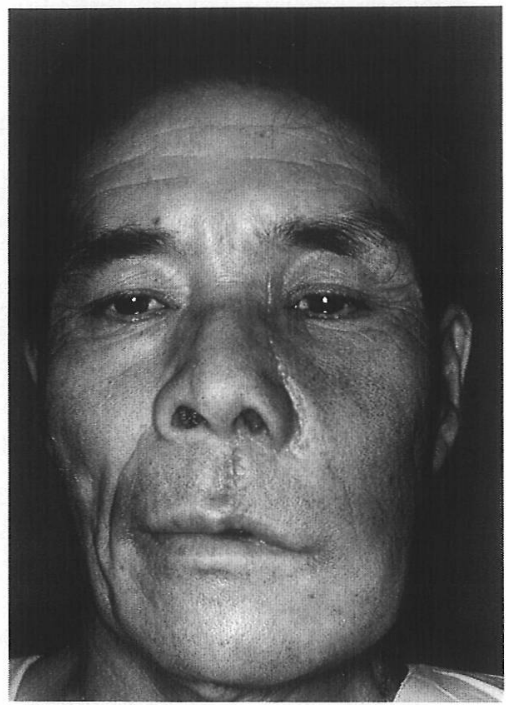

図 2 眼球の位置は良好に保たれ下眼瞼部の陷凹は, 腸骨移植によって防止されているが，上口唇の 皮切淛痕が目立つ。

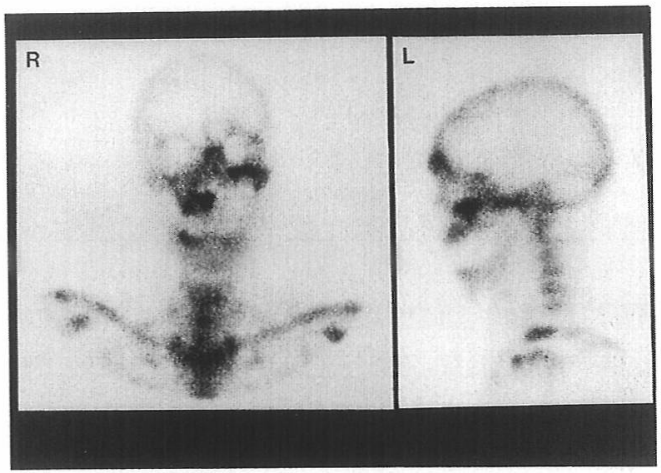

図 $399 \mathrm{~m}$ Tc scintigram. 移植骨に一致して uptake がみられ生着しているととを示している。 
りぎりのととろに置き，眼窩下縁に至るまでは 皮虚と眼輪筋との間を䟝離し，眼窩下縁に達し たとき眼窩骨膜と眼球脂肪との間で剝離して, その後は従来の上顎全摘術に準じて en bloc に 上顎を切除した。また眼窩底は大腿筋膜にて八 ンモック状につり上げ，前腕皮弁にて術創全体 を被覆した（図 4，5)。

\section{考察}

上顎全摘後に生じる問題点としては，術創の 洀痕収縮による顔面変形と支持体の喪失による
眼球沈下，下眼瞼部，前頓部の陥凹，そして 口蓋歯列の啔失であり，その三点が再建目標之 なる．顔面の皮切法については，上顎全摘を行 う際の術野の問題之同時に，顔面痈痕と口唇機 能という点を考慮する必要があり，乙れもまた 口内法による上顎全摘術などの試みあある. Killian-星野の皮膚切開では，Weber 法に準じ た補助切開を入れない限り外側上方への永離範 囲が，之くに眼窩側方の㓦離が制限されている (図 6)。また症例 1 で見られるごとく上口唇を
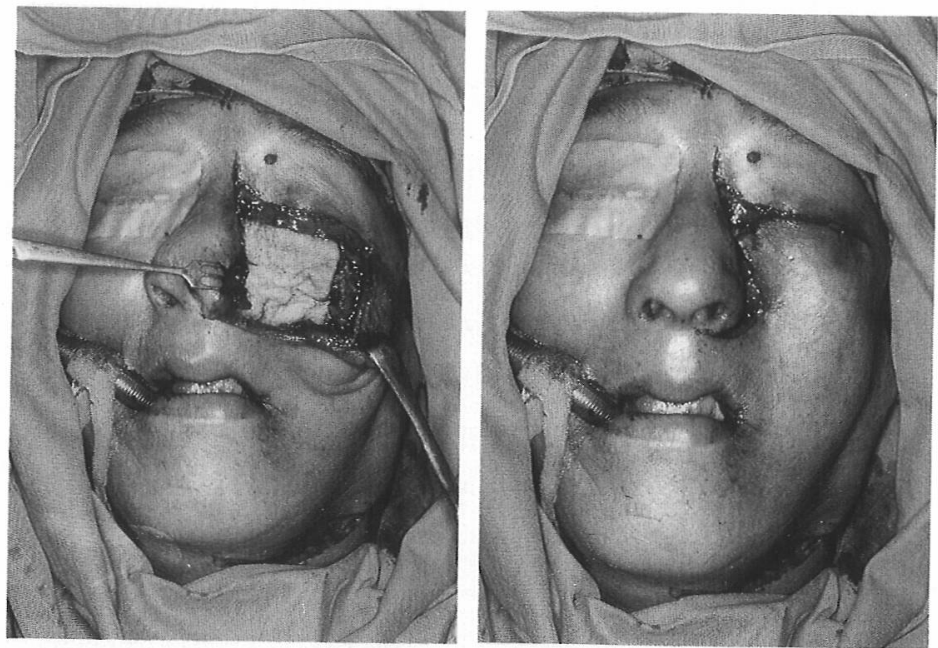

図 4 左：上顎全摘を行い前腕皮弁を入れたところである。 右：側鼻切開および下眼瞼切開創を縫合するところである。
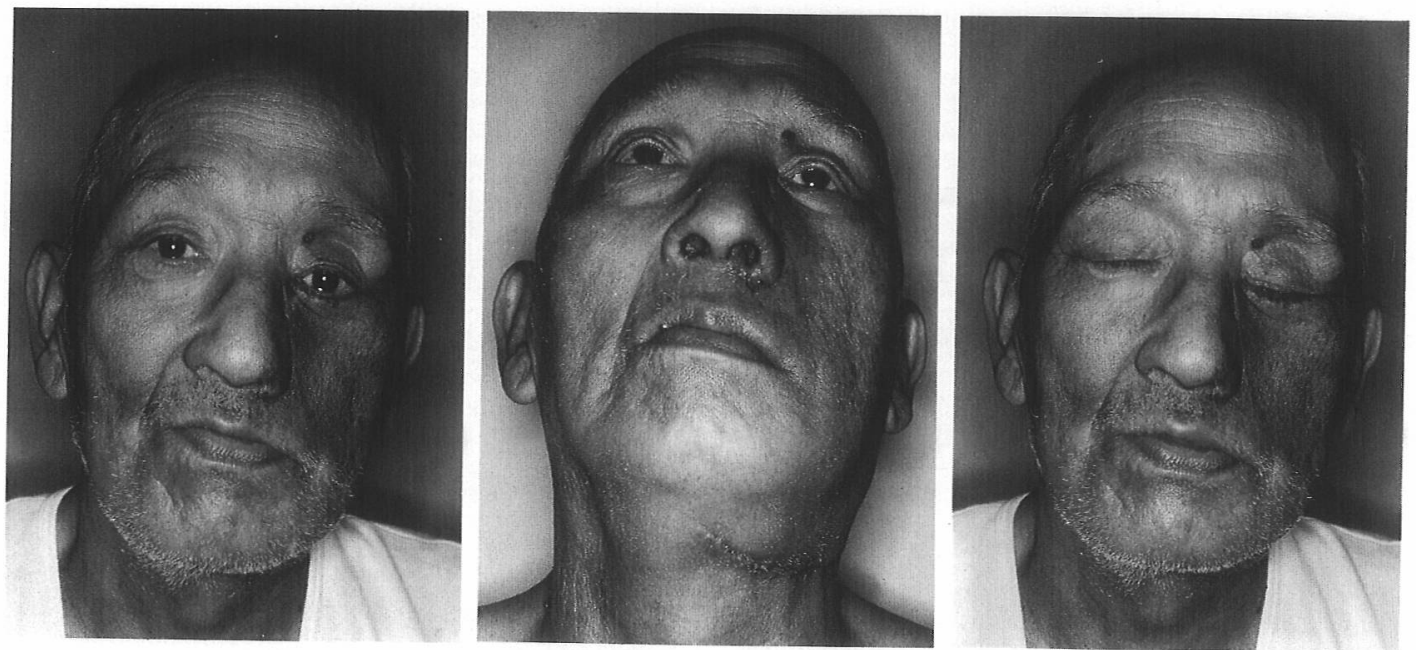

図 5 術前照射のため色素沈着はみられるが，顔面の全体的な整容性は 開眼，閉眼時とも良好である。 
切断するため，口唇機能の障害と同時に整容的 な面からも問題がある.上顎洞の解剖学的形態 は拉沶よそ逆三角錐体であり，上顎全摘に必要 な皮膚切開は底辺を下眼瞼に置き，頂点を外鼻 孔内側とする逆三角形の部分を明視下に置くこ とができれば充分であると思われる，そのため 症例 2 では下眼瞼切開と側鼻切開を併用するこ とによって上顎全摘を行った。 また下眼瞼の皮 切については，美容外科に打ける下眼瞼形成術 に準じて睷毛の直下に切開線を入れ，眼輪筋と 皮膚との間を剝離し，眼浻下縁に達した時点に て眼窩骨膜と眼球脂肪との間を剝離し，そのほ かの操作は従来の方法に準じた。 下眼瞼切開は 必要に応じて外側方に延長できる，乙の皮膚切 開では剶離の範囲も逆三角形となり，視野む広 くまた術後の瘢痕も目立たなく，さらに口唇の integration を保存するとともに整容的な効果が 大きい.

支持体の再建に関しては，骨移植が必要であ り，とくに煩骨まで切除しなければならないと きなどは，眼球の陥凹沈下に加え，前煩部の陥 凹の原因となる，乙の変形は遊離あるいは有茥 あるいは血管柄付遊離骨移植によって修復でき る. 遊離腸骨移植を行った症例を示したが, $99 \mathrm{mTc}$ scintigram にて uptake がみられ生着 していることが示されており，血流の豊富な皮

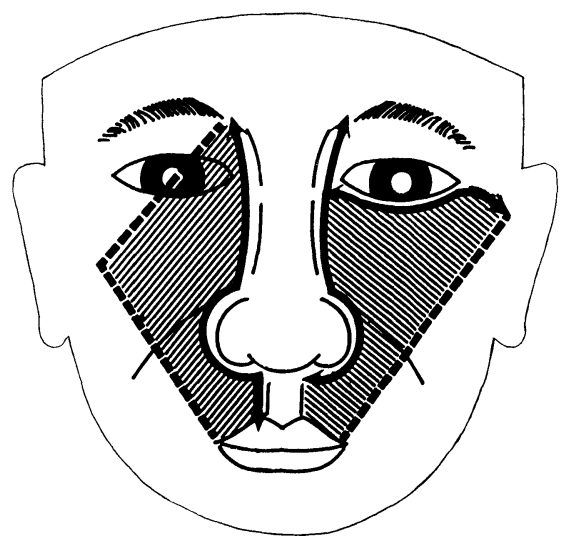

図6 左: Killian-星野皮膚切開.

右 : 側鼻切開十下眼瞼切開による剥離 の範囲を斜線にて示す.
弁にて被覆するので，生着に関してはあまり問 題はないと思われる. 長期的にみた場合, 二次 的な骨吸収の問題は考えなければならないが， 骨移植の目的は眼窩内容物の支持体之前頓部の 陥凹防止であるので物理的な強度は必要とせず 遊離骨移植でも可能であろうと思われる.

あうひとつの支持体の再建は口蓋である，硬 口蓋の欠損に対しては，義歯によって閉鎖して いるが支持体のないところに義歯を装着してい るので，その義歯で物を嘴むことは出来ない. 従って硬い組織によって口盖を形成しなければ ならないが，その第一選択は骨移植によって義 歯床をつくることであり, 圧力, 物理的刺激, 吸収の問題を考え併せると遊離骨移植よりは血 管柄付遊離骨移植の方が望ましいと思われる。 Swartzら ${ }^{12)}$ は，血管柄付肩甲骨移植を試みてい るが，義歯装着までいたらないのが現状であり， 将来的な問題を残している.

次に裏打ちに用いる皮弁の選択に関しては, 主として D-P 皮弁を用いた有茎皮弁 ${ }^{11)}$ と遊離 皮弁とを比較すると, 段階手術, 術後の体位固 定, 気管切開の必要性等の点で遊離皮弁を利用 することによって患者への負担は軽減すると思 われる，つぎに遊離皮弁の選択が問題となるが， その条件としては，上䪽全摘創は凹凸があるた め易橈性が求められるが，皮弁の mass として は多くを必要としない，広背筋皮弁および腹直 筋皮弁は mass が大きく, 術創全体が充填され 義歯装着は不可能となる。また煩骨を広範囲に 切除した症例では支持組織再建を併用しない限 り患側煩部が drooping を起こしやすいという 問題がある．肩甲骨皮弁は皮弁自体が柔らかく， 肩甲骨の一部分とと屯に移植することが可能で， さらに donor site は単純縫縮ができ植皮は必要 ない，衣服に隠れる場所でああり donor siteの 問題は少ないが，栄養血管の長さが限られてい る. 血管柄の長さは約 $6 \mathrm{~cm}$ と言われている ${ }^{13)}$ が, 著者らの経験でも浅側頭動静脈または顔面動静 脈など吻合側血管をかなり保存しないかぎり血 管吻合は難しく，とくに浅側頭動脈からの抗癌 
剂の動注を行う場合が多いので，比較的使いに くい皮弁である。さらに肩甲骨ととあに再建す る場合は，眼窩底の再建に用いるのか，口蓋の 再建に用いるのか, 将来的な視点に立って再建 を行う必要があるように思われる．前腕皮弁は， donor site の整容性が最大の問題であるが，長 期的には前腕手指の栄養血管が一本になるため 将来的な安全性についても検討しなければなら ない。しかしながら皮弁の持つ易橈性と，創の 被覆能力，さらに長い血管柄などからその利点 を考えると，上顎全摘創の被覆には用い易い皮 弁である ${ }^{14)}$.

\section{まとめ}

上顎癌に対する三者併用療法の中で，上顎全 摘を基本方針とするかぎり，根治性と同時に， 整容性，機能性といった問題を解決する必要が ある. 皮虐皮切の位置, 支持組織の再建, 裏打 ち皮弁の選択について，症例を紹介しながら付 随する問題点を挙げ考察した。

\section{参考文献}

1) 佐藤靖雄, 森田 守, 高橋廣臣 : 上顎癌の形態, 機能保存治療について. 耳鼻 $17: 89 \sim 99,1971$.

2) 森田 守, 宮田 守, 五十嵐丈人, 他 : 上顎癌の 併用療法一乙とに $\mathrm{T}_{4}$ 症例の治療法について。 日 耳鼻 $92: 169 \sim 175,1989$.

3）今野昭義, 戸川 清, 東紘一郎, 他 : 上顎全摘 拡大全摘後欠損の一次的再建術 D-P 皮弁の利用 について. 耳喉 78 : 599 611， 1985.

4）今野昭義, 戸川 清, 飯塚桂司：上䫟全摘後の一 次的再建術之術後形態, 機能の評価. 形成外科 $22: 521 \sim 522,1979$.

5 ) Konno A, Togawa K and Inoue S : Analysis of the results of our combined therapy for maxi- llary cancer. Acta Otolaryngol Suppl $372: 1 \sim$ 16, 1980.

6 ) Konno A, Togawa K and Iizuka K : Primary reconstruction after total or extended total maxillectomy for maxillary cancer. Plast Reconstr Surg $67:$ 440 448, 1981.

7 ）今野昭義, 藤吉達也：口腔癌, 上顎癌に対する即 時再建術を組み入れた複合療法一遠隔成績之術後 形態および機能の評価. 癌の臨床 $28: 103 \sim 110$, 1982.

8）今野昭義：上顎癌に対する根治切除術の適応.耳 鼻臨床 $78 ： 687 \sim 689,1985$.

9 ）今野昭義, 花沢 秀, 岡本美孝, 他 : 上顎癌の集 学的治療. 癌と化学療法 $14: 1772 \sim 1780,1987$.

10）飯塚桂司, 古田 康, 川浪 貢 : $5-\mathrm{Fu}$ 単独大量 療法之頭頸部癌の集学的治療. 耳鼻臨床 $82: 421$ $\sim 428,1989$.

11）飯塚桂司, 高橋国広, 広瀬正雄：上顎全摘症例に 対する D-P 皮弁再建の有用性について. 北海道 頭頸部腫瘍研究会会誌 $2: 22 \sim 25 ， 1985$.

12) Swartz W, Banis J, Newton D, et al : The osteocutaneous scapular flap for mandibular and maxillary reconstruction. Plast Reconstr Surg $77: 530 \sim 545,1986$.

13) Baker $S$ and Sullivan $M$ : Osteocutaneous free scapular flap for one-stage mandibular reconstruction. Arch Otolaryngol $114: 267 \sim 277$, 1988.

14）飯塚桂司, 古田 康, 川浪 貢: 前腕皮弁作成の 一工夫. 北海道頭頸部腫瘍研究会会誌 $8: 56 \sim 58$, 1989.

$$
\left(\begin{array}{l}
\text { 原稿受付 : 平成元年 } 12 \text { 月 } 15 \text { 日 } \\
\text { 原稿採択 : 平成 } 2 \text { 年 } 1 \text { 月 } 19 \text { 日 } \\
\text { 別刷請求先 : 飯塚桂司 } \\
\text { T } 085 \text { 釧路市春湖台 } 1-12 \\
\text { 市立釗路総合病院耳鼻咽喉科 }
\end{array}\right)
$$

